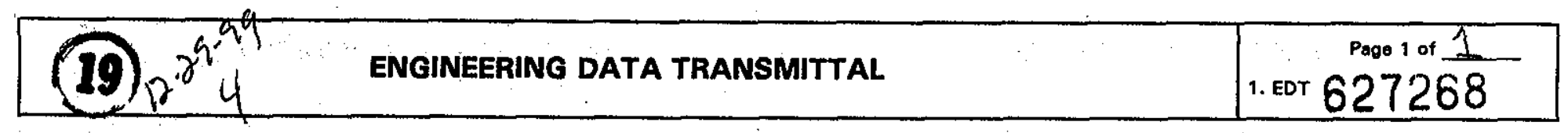

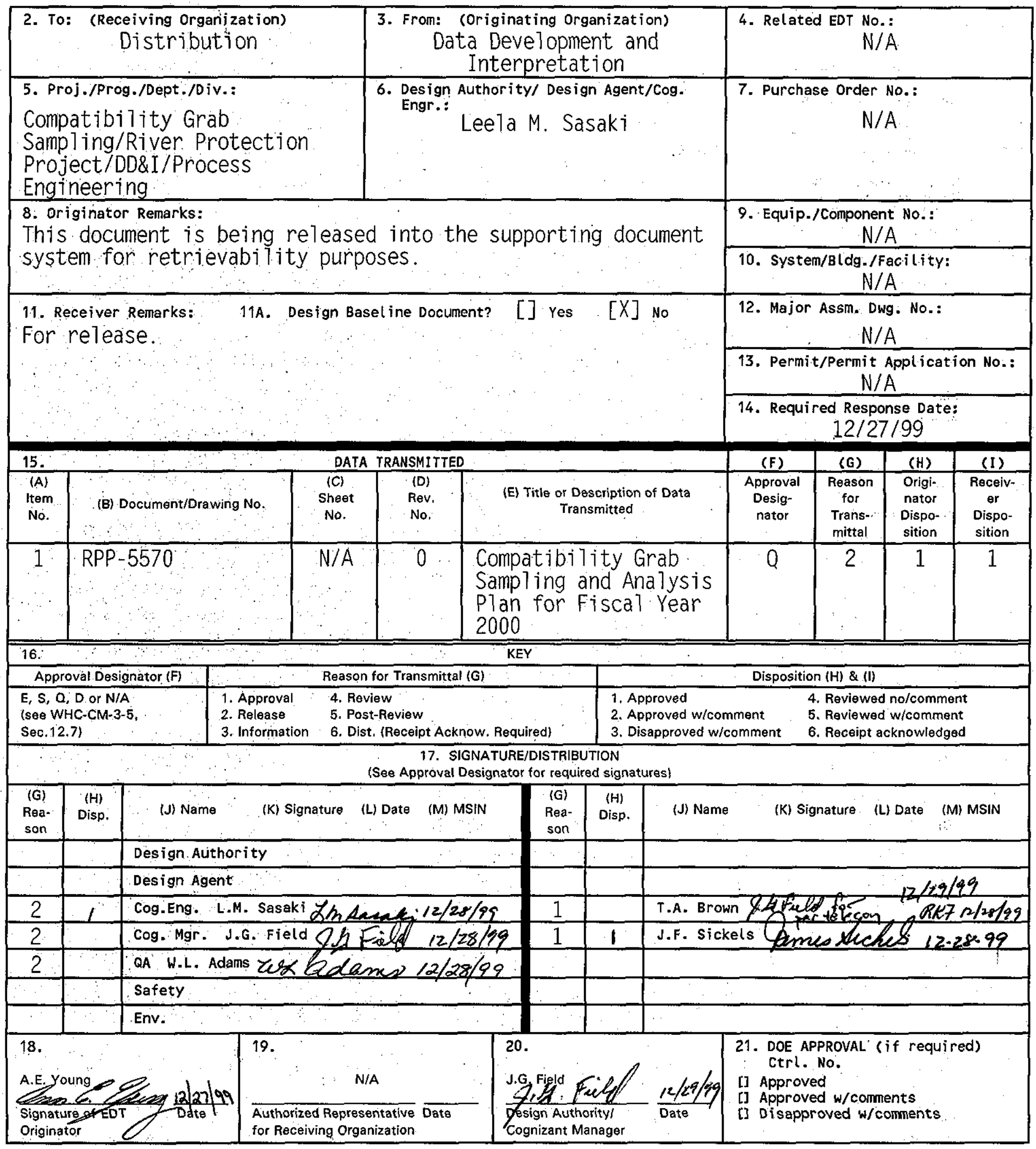

BD-7400-172-2 (05/96) GEF097 


\begin{tabular}{|c|c|c|c|c|c|}
\hline \multicolumn{6}{|c|}{ DISTRIBUTION SHEET } \\
\hline \multirow[b]{2}{*}{ Distribution } & \multirow{2}{*}{\multicolumn{3}{|c|}{$\begin{array}{l}\text { From } \\
\text { Data Developn } \\
\text { Interpreta }\end{array}$}} & \multicolumn{2}{|l|}{ Page 1 of 1} \\
\hline & & & & \multicolumn{2}{|c|}{ Date $12 / 27 / 99$} \\
\hline \multirow{2}{*}{\multicolumn{4}{|c|}{$\begin{array}{l}\text { Project Title/Work Order } \\
\text { RPP-5570, Rev. 0, "Compatibility Grab Sampling and Analysis Plan } \\
\text { for Fiscal Year } 2000 "\end{array}$}} & \multirow{2}{*}{\multicolumn{2}{|c|}{$\begin{array}{ll}\text { EDT No. } & \text { EDT-627268 } \\
\text { ECN No. } & \text { N/A }\end{array}$}} \\
\hline & & & & & \\
\hline Name & MSIN & $\begin{array}{c}\text { Text } \\
\text { With All } \\
\text { Attach. }\end{array}$ & Text Only & $\begin{array}{l}\text { Attach./ } \\
\text { Appendix } \\
\text { Only }\end{array}$ & $\begin{array}{l}\text { EDT/ECN } \\
\text { Only }\end{array}$ \\
\hline $\begin{array}{l}\text { CH2M Hill Hanford Group, Inc. } \\
\text { W. L. Adams } \\
\text { J. H. Baldwin } \\
\text { T. M. Blaak } \\
\text { R. G. Brown } \\
\text { J. N. Doeler } \\
\text { J. G. Field } \\
\text { K. D. Fowler } \\
\text { D. J. Green } \\
\text { J. Jo } \\
\text { R. E. Larson } \\
\text { L. M. Sasaki } \\
\text { J. F. Sickels } \\
\text { G. A. Stanton } \\
\text { R. R. Thompson } \\
\text { T.C.S.R.C. }\end{array}$ & $\begin{array}{l}\text { S5 }-15 \\
\text { R3- } 73 \\
\text { S5 }-13 \\
\text { S7 }-12 \\
\text { T4-07 } \\
\text { R2-12 } \\
\text { R2-11 } \\
\text { S7 }-90 \\
\text { R2-12 } \\
\text { T4-07 } \\
\text { R2-12 } \\
\text { S7-03 } \\
\text { S7-01 } \\
\text { R2-12 } \\
\text { R1-10 }\end{array}$ & $\begin{array}{l}x \\
x \\
x \\
x \\
x \\
x \\
x \\
x \\
x \\
x \\
x \\
x \\
x \\
x \\
x\end{array}$ & & & \\
\hline $\begin{array}{ll}\text { Fluor } & \text { Hanford } \\
\text { R. } & \text { Akita } \\
\text { K. E. Bell } \\
\text { G. A. Clark } \\
\text { R. A. Esch } \\
\text { R. K. Fuller } \\
\text { K. L. Powel1 } \\
\text { F. H. Steen }\end{array}$ & $\begin{array}{r}T 6-50 \\
\text { T6-12 } \\
\cdot \mathrm{T} 6-12 \\
\mathrm{~T} 6-12 \\
\mathrm{~T} 6-12 \\
\mathrm{~S} 3-30 \\
\mathrm{~T} 6-12\end{array}$ & $\begin{array}{l}x \\
x \\
x \\
x \\
x \\
x \\
x \\
x\end{array}$ & & & \\
\hline$\frac{\text { Lockheed Martin Services, Inc. }}{\text { Central Files }}$ & B1-07 & $x$ & & & \\
\hline$\frac{\text { Numatec Hanford Corp. }}{\text { W. I. Winters }}$ & $T 6-50$ & $x$ & & & \\
\hline $\begin{array}{l}\text { Office of River Protection } \\
\text { W. Liou } \\
\text { DOE/RL Reading Room }\end{array}$ & $\begin{array}{l}H 6-60 \\
H 2-53\end{array}$ & $\begin{array}{l}x \\
x\end{array}$ & & & \\
\hline $\begin{array}{l}\text { Waste Management Federal Serv } \\
\text { T. A. Brown } \\
\text { C. M. Seidel }\end{array}$ & 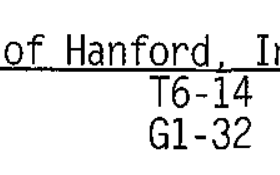 & $\begin{array}{l}x \\
x\end{array}$ & & & \\
\hline
\end{tabular}




\section{Compatibility Grab Sampling and Analysis Plan for Fiscal Year 2000}

Leela M. Sasaki

CH2M Hill Hanford Group, Inc., Richland, WA 99352

U.S. Department of Energy Contract DE-AC06-96RL13200

$\begin{array}{lll}\text { EDT/ECN: } & \text { EDT }-627268 & \text { UC: 2070 } \\ \text { Org Code: } & 74 \mathrm{~B} 10 & \text { CACN/COA: 102289/ES12 } \\ \text { B\&R Code: } & \text { EW 3120074 } & \text { TotaT Pages: } 25\end{array}$

Key Words: Compatibility, Grab, Sampling. Analysis, Plan, Fiscal Year 2000, FY 2000

Abstract: N/A

TRADEMARK DISCLAIMER. Reference herein to any specific commercial product; process, or service by trade name, trademark, manufacturer, or otherwise, does not necessarily constitute or imply its endorsement, recommendation, or favoring by the United States Government or any agency thereof or its contractors or subcontractors.

Printed in the United States of America. To obtain copies of this document, contact: Document Control Services, P.O. Box 950, Mailstop H6-08, Richland WA 99352, Phone (509) 372-2420; Fax (509) 376-4989.
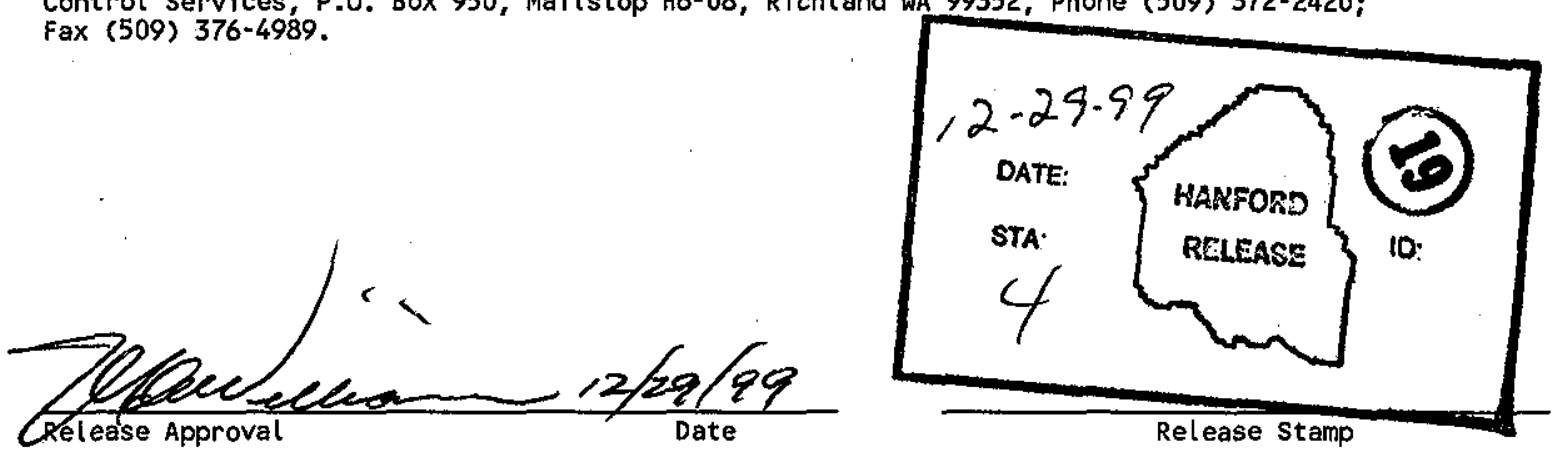

Approved for Public Release 
RPP-5570

Revision 0

\section{Compatibility Grab Sampling and Analysis Plan for Fiscal Year 2000}

L. M. Sasaki

CH2M HILL Hanford Group, Inc.

Prepared for the U.S. Department of Energy

Office of River Protection 


\section{TABLE OF CONTENTS}

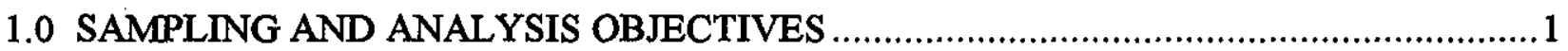

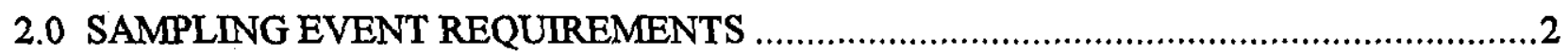

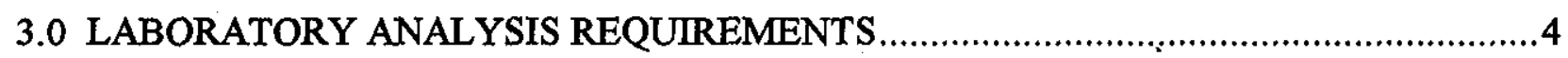

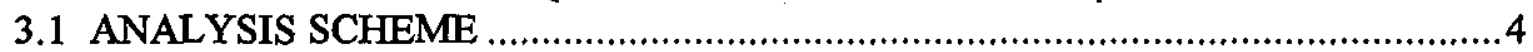

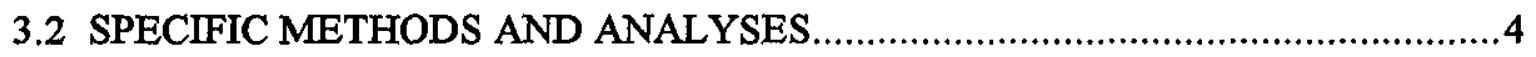

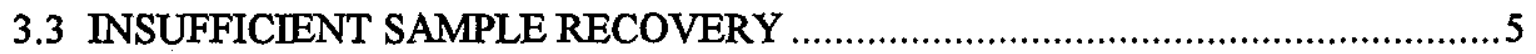

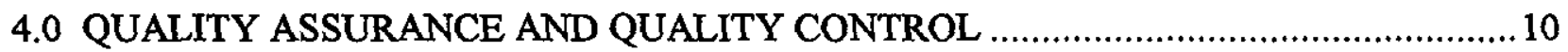

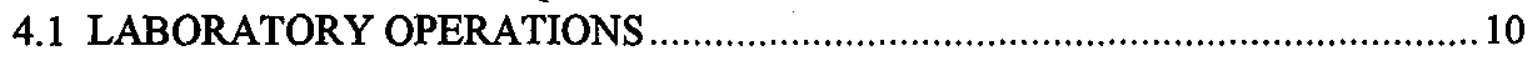

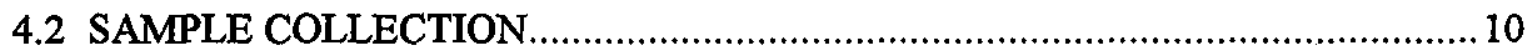

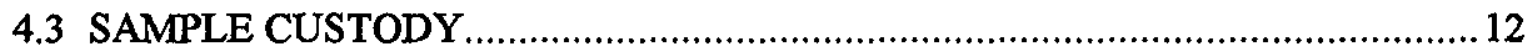

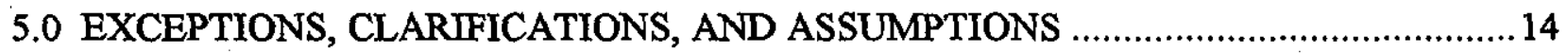

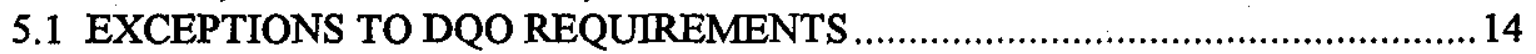

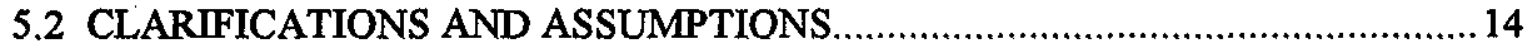

5.3 PRIORITIES FOR COMPATIBILITY GRAB SAMPLES ……...........................14

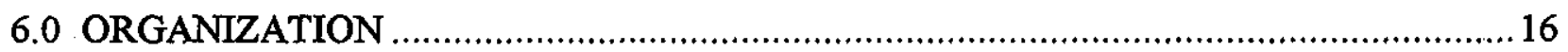

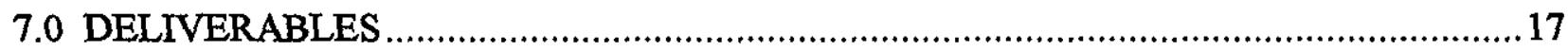

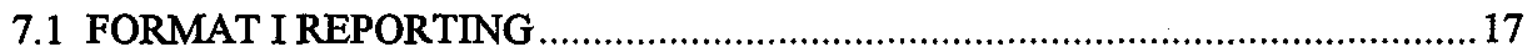

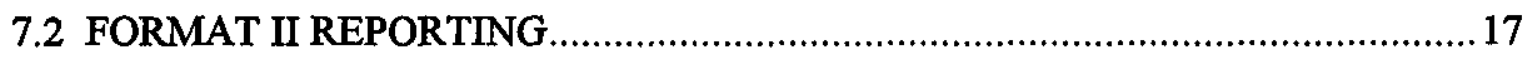

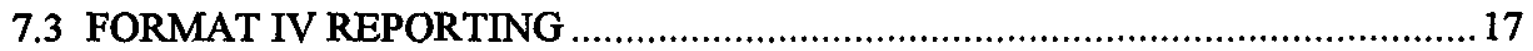

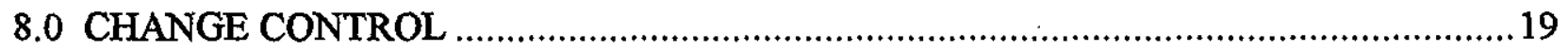

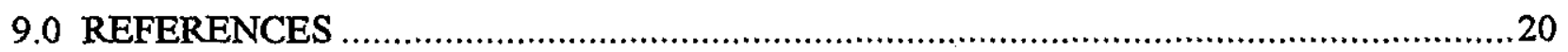

\section{LIST OF TABLES}

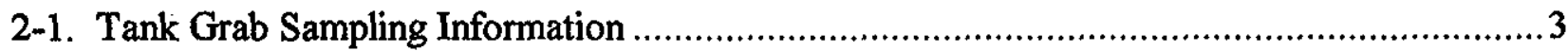

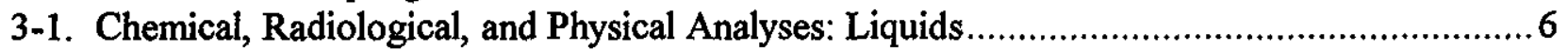

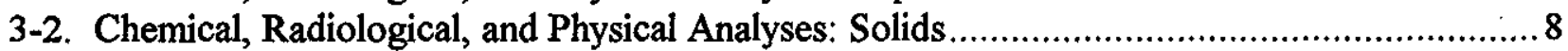

4-1. QC Precision and Accuracy Requirements for the Analyses ............................................11

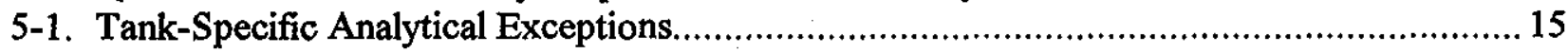

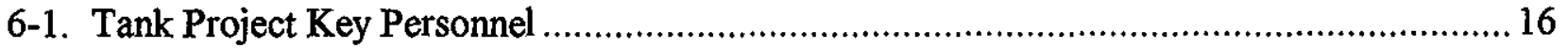


RPP-5570, Rev. 0

\section{LIST OF ABBREVIATIONS}

$\begin{array}{ll}\text { AEA } & \text { alpha energy analysis } \\ \text { CHG } & \text { CH2M HimL Hanford Group, Inc. } \\ \text { CPO } & \text { Characterization Project Operations } \\ \text { CVAA } & \text { cold vapor atomic absorption } \\ \text { DQO } & \text { data quality objective } \\ \text { DSC } & \text { differential scanning calorimetry } \\ \text { EQL } & \text { estimated quantitation limit } \\ \text { FDH } & \text { Fluor Daniel Hanford, Inc. } \\ \text { GEA } & \text { gamma energy analysis } \\ \text { GFAA } & \text { graphite furnace atomic absorption } \\ \text { g/mL } & \text { grams per milliliter } \\ \text { IC } & \text { ion chromatography } \\ \text { ICP/AES } & \text { inductively coupled plasma - atomic emission spectroscopy } \\ \text { ICP/MS } & \text { inductively coupled plasma - mass spectrometry } \\ \text { J/g } & \text { joules per gram } \\ \text { LCS } & \text { laboratory control standard } \\ \text { LFL } & \text { lower flammability limit } \\ \text { MDA } & \text { minimum detectable activity } \\ \text { N/A } & \text { not applicable } \\ \text { NHC } & \text { Numatec Hanford Corporation } \\ \text { NP } & \text { not performed } \\ \text { QA } & \text { quality assurance } \\ \text { QC } & \text { quality control } \\ \text { RPD } & \text { relative percent difference } \\ \text { RPP } & \text { River Protection Project } \\ \text { SAP } & \text { sampling and analysis plan } \\ \text { TBD } & \text { to be determined } \\ \text { TGA } & \text { thermogravimetric analysis } \\ \text { TIC } & \text { total inorganic carbon } \\ \text { TOC } & \text { total organic carbon } \\ \text { wt\% } & \text { weight percent } \\ \mu \text { Ci/g } & \text { microcuries per gram } \\ \mu \text { Ci/mL } & \text { microcuries per milliliter } \\ \mu \mathrm{g} / \mathrm{g} & \text { micrograms per gram } \\ \mu \mathrm{g} / \mathrm{mL} & \text { micrograms per milliliter } \\ & \end{array}$


RPP-5570, Rev. 0

\subsection{SAMPLING AND ANALYSIS OBJECTIVES}

This sampling and analysis plan (SAP) identifies characterization objectives pertaining to sample collection, laboratory analytical evaluation, and reporting requirements for grab samples obtained to address waste compatibility. It is written in accordance with requirements identified in Data Quality Objectives for Tank Farms Waste Compatibility Program (Mulkey et al. 1999) and Tank Farm Waste Transfer Compatibility Program (Fowler 1999).

In addition to analyses to support Compatibility, the Waste Feed Delivery program has requested that tank samples obtained for Compatibility also be analyzed to confirm the high-level waste and/or low-activity waste envelope(s) for the tank waste (Baldwin 1999). The analytical requirements to confirm waste envelopes are identified in Data Quality Objectives for TWRS Privatization Phase I: Confirm Tank T is an Appropriate Feed Source for Low-Activity Waste Feed Batch X (Nguyen 1999a) and Data Quality Objectives for RPP Privatization Phase I: Confirm Tank $T$ is an Appropriate Feed Source for High-Level Waste Feed Batch $X$ (Nguyen 1999b). 


\subsection{SAMPLING EVENT REQUIREMENTS}

Table 2-1 identifies tanks scheduled to be grab sampled to address waste compatibility. The number of samples, the riser to be used for sampling, and the elevations and depths at which the samples are to be obtained are identified. This SAP will be revised and updated as necessary to include additional grab sample events.

Prior to sampling, the dome space (below the riser) shall be measured for the presence of flammable gases. The measurement shall be taken from within the dome space and the data reported as a percentage of the lower flammability limit (LFL). The results shall be transmitted to River Protection Project (RPP) Process Engineering within ten working days of the sampling event (Schreiber 1998). If the results are above 25 percent of the LFL when analyzing by gas . chromatography/mass spectrometry or gas-specific monitoring gauges or above 10 percent of the LFL when analyzing with a combustible gas meter RPP Process Engineering shall notify the Flammable Gas Safety Project. The necessity for recurring sampling for flammable gas concentration and the frequency of such sampling will be determined by the Flammable Gas Safety Project. Any additional vapor sampling is not within the scope of this SAP.

Samples shall be obtained using plant operating procedure TO-080-403, Supernatant or Sludge Sampling of Waste Storage Tanks.

If quality-affecting changes to the sampling requirements must be made (including the risers or samples to be obtained), the change must be recorded and approved by the cognizant engineer and tank coordinator before sampling. This information may be recorded on a permanent data sheet or recorded directly in the work packages. These work packages contain the operating procedures and the chain-of-custody records for the sampling events.

No field/trip blanks are required during these sampling events. Samples should be shipped to the laboratory within three calendar days from the time of sampling. 
RPP-5570, Rev, 0

Table 2-1. Tank Grab Sampling Information

\begin{tabular}{|c|c|c|c|c|c|}
\hline 4 & 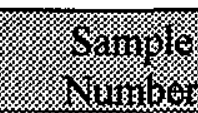 & 9.9. & 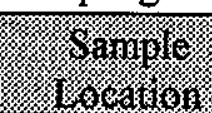 & 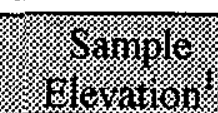 & 3.7. \\
\hline 241-SY-102 & $\begin{array}{l}2 S Y-99-5 \\
2 S Y-99-6 \\
2 S Y-99-7 \\
2 S Y-99-8 \\
2 S Y-99-9\end{array}$ & $\begin{array}{l}\text { Supernate } \\
\text { (surface) } \\
\text { Supernate } \\
\text { Supernate } \\
\text { Supernate } \\
\text { Supernate }\end{array}$ & Riser 002 & $\begin{array}{l}1 \text { in. below } \\
\text { liquid level } \\
336 \text { in. } \\
252 \text { in. } \\
156 \text { in. } \\
72 \text { in. }\end{array}$ & $\begin{array}{l}\text { zipcord } \\
\text { reading }+1 \text { in. } \\
337 \text { in. } \\
421 \text { in. } \\
517 \text { in. } \\
601 \text { in. }\end{array}$ \\
\hline
\end{tabular}

Notes:

${ }^{1}$ Sample elevation is defined as distance from tank bottom to mouth of sample bottle; sample depth is defined as the distance from the top of the riser to the mouth of the sample bottle. 
RPP-5570, Rev. 0

\subsection{LABORATORY ANALYSIS REQUIREMENTS}

\subsection{ANALYSIS SCHEME}

In order to comply with Mulkey et al. (1999) Fowler (1999), and Baldwin (1999) the following steps shall be performed on each sample. All samples shall be analyzed to meet the requirements of the Compatibility program. Direction on the analysis of samples for Waste Feed Delivery lowactivity waste and high-level waste envelope analytes is provided in Table 5-1.

- Record visual observations such as color and clarity of the liquid and the presence of any solid particles in the liquid. Record the volume of settled solids, if present.

- Closely inspect the liquid sample for the presence and approximate volume of any potential organic layers. Record the volume of separable organic phase, if present.

- $\quad$ For samples expected to be supernatant samples:

- Remove sufficient aliquots of liquid and perform the analyses listed in Table 3-1.

- If the sample has greater than 25 percent settled solids, contact the tank coordinator for further instructions.

- For samples expected to contain solids:

- Allow the solids to settle, record the volume percent settled solids, and then decant the liquid (supernatant) from the solids. Unless specified in Section 5, no analyses are required for the decanted supernatant.

- Centrifuge the solids, record the bulk density of the "wet" sludge and the volume percent centrifuged solids, and then decant the liquid (interstitial liquid) from the centrifuged solids.

- Remove sufficient aliquots of interstitial liquid and perform the analyses listed in Table 3-1.

- Remove sufficient aliquots of centrifuged solids and perform the analyses as shown in Table 3-2.

- Archive remaining sample material for possible future analyses.

Opportunistic analyses as defined in Kristofzski (1996) are to be included when the laboratory is not operating at maximum capacity. Any decisions, observations, or deviations from this work plan during the sample breakdown and analyses shall be documented in writing with justification. These decisions, observations, and deviations shall be reported in the data report. The reporting formats for analyses are specified in Tables 3-1 and 3-2 and are described in Section 7.0

\subsection{SPECIFIC METHODS AND ANALYSES}

The analyses in Table 3-1 to be performed on the liquid grab samples are based on the compatibility data quality objective (DQO) and low-activity waste and high-level waste envelopes referenced in Section 1.0. The laboratory procedure numbers to be used for the analyses are included in the tables. Sample preparation procedures that may be used at the 222-S Laboratory are LA-549-141 for fusion digestion of solids, LA-505-159 or LA-505-163 for acid digestion of samples, and LA-504-101 for water leach of solids. 


\subsection{INSUFFICIENT SAMPLE RECOVERY}

If the amount of material recovered from samples taken from the tank is insufficient to perform the analyses requested in the SAP, the laboratory shall notify the tank coordinator within one working day. A prioritization of the analyses is provided in Section 5.3. Any analyses prescribed by this SAP, but not performed, shall be identified in the appropriate data report with justification for non-performance. 


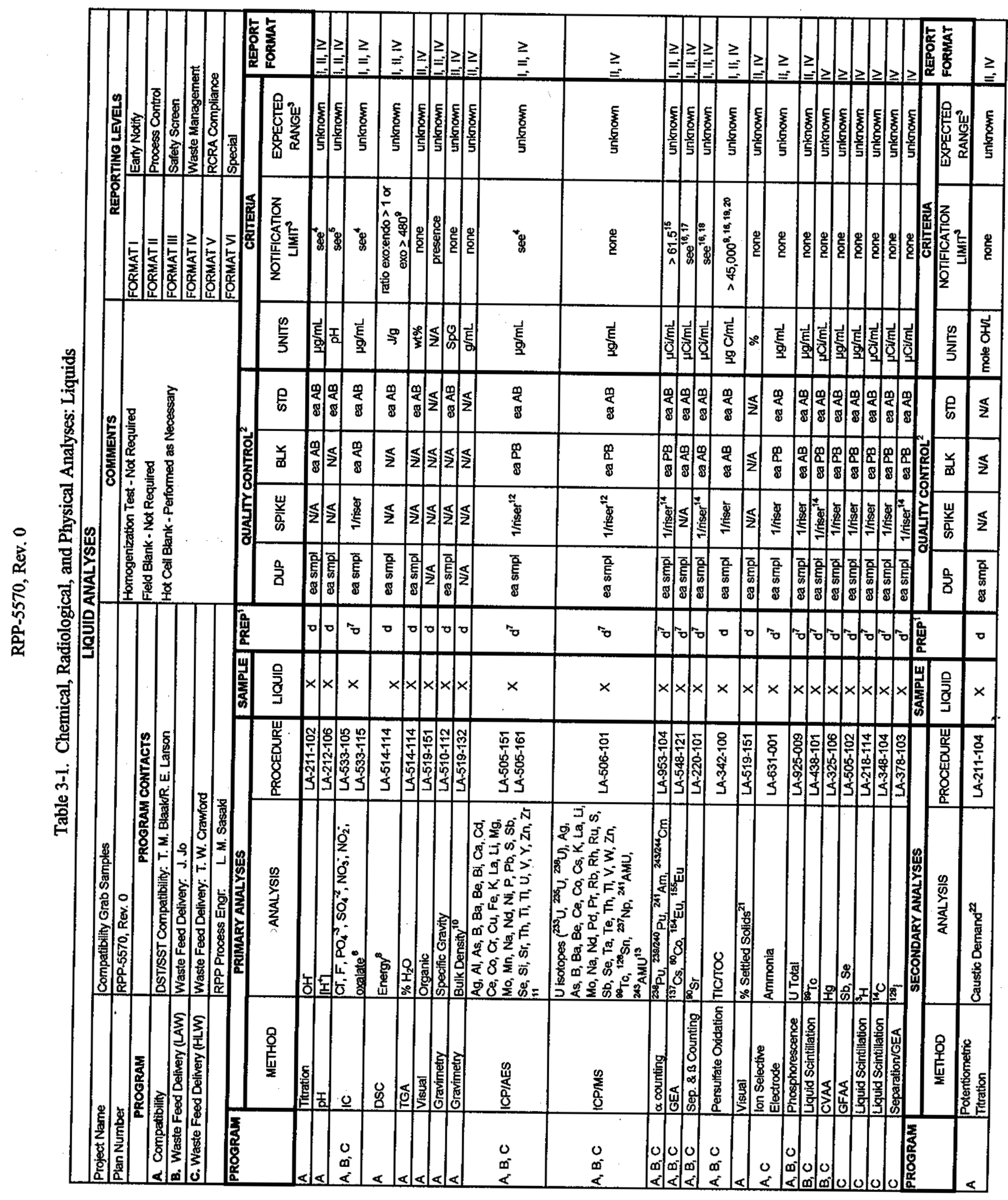



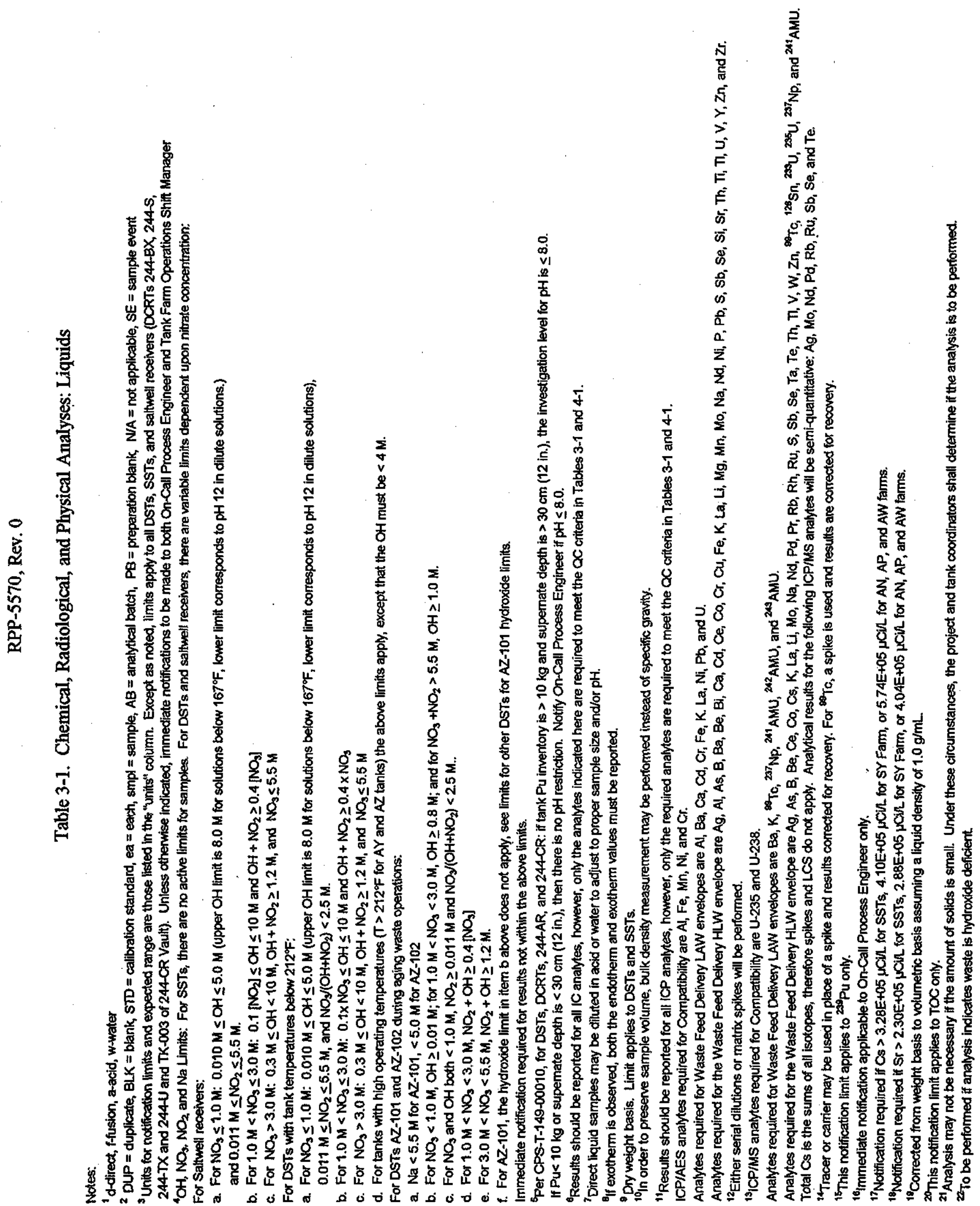


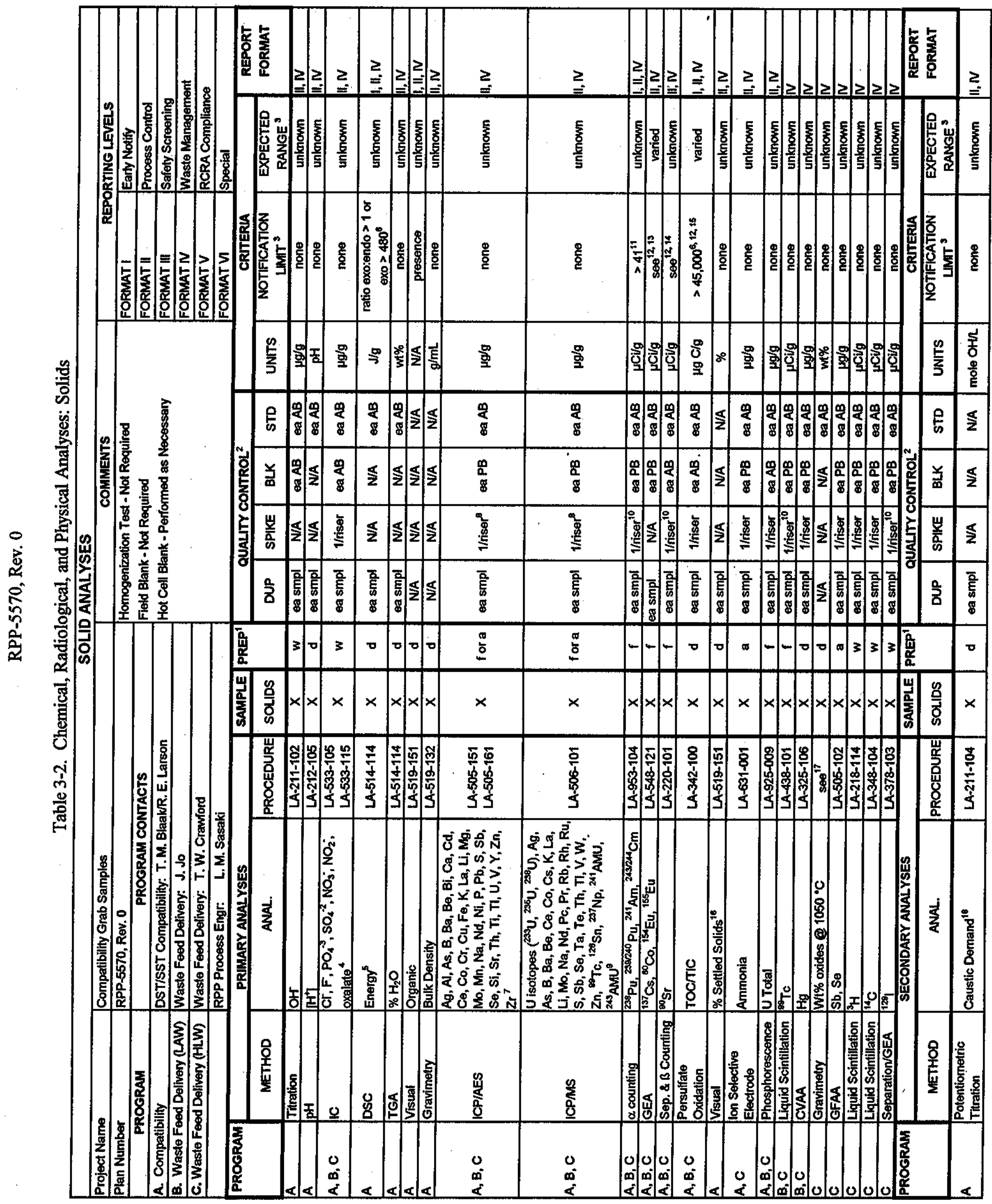




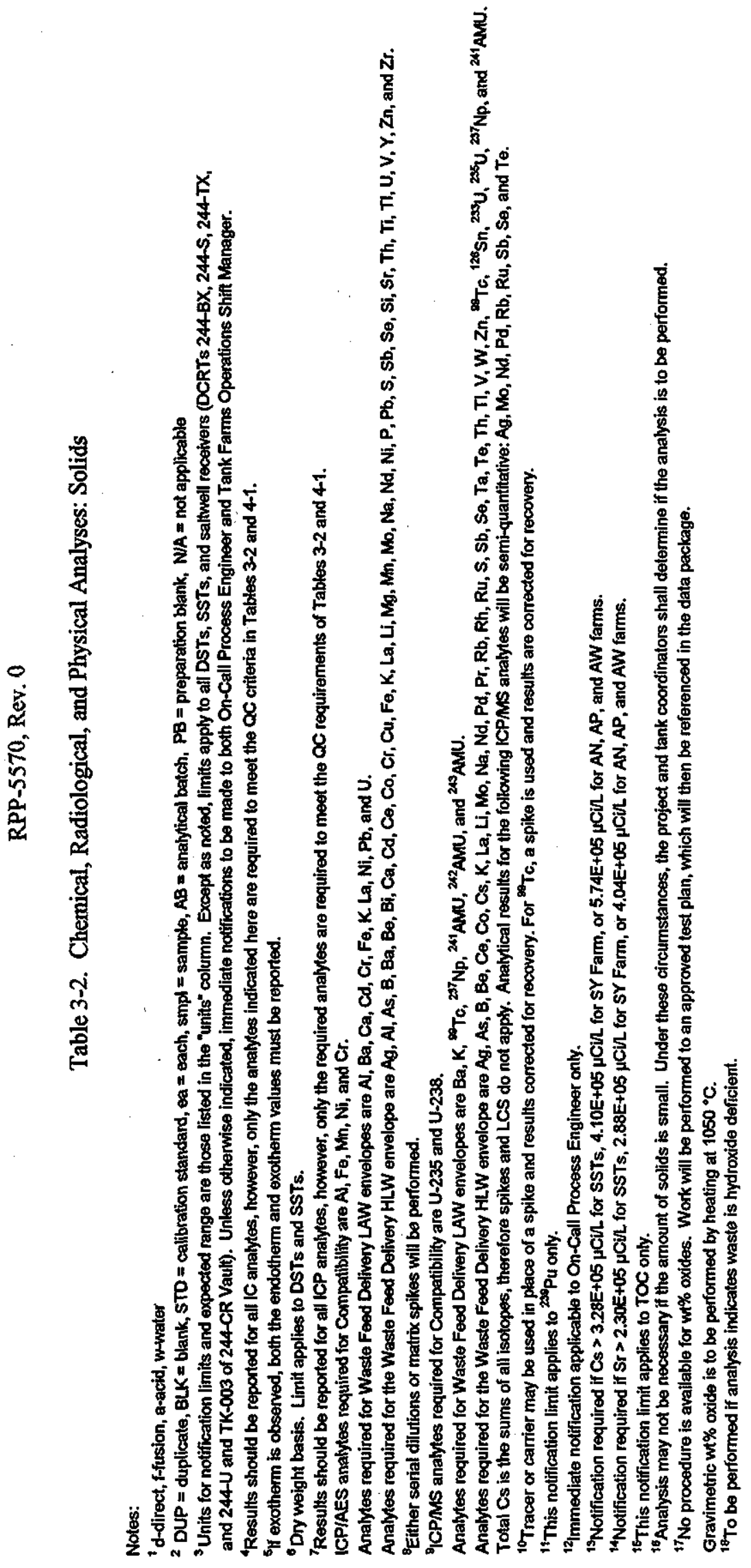




\subsection{QUALITY ASSURANCE AND QUALITY CONTROL}

Processes, services, activities, and conditions adverse to quality which do not conform to requirements specified in this SAP or references herein shall be controlled to prevent inadvertent use. Nonconforming sampling and analysis processes shall be identified, controlled, reported, and dispositioned as required by Nonconforming Item Reporting and Control (LMHC 1999).

Quality requirements for conducting Characterization Project sampling and analysis are described in Tank Waste Remediation System Characterization Project, Quality Policies (Board 1998) and this SAP. Characterization Project sampling and analysis shall be conducted in conformance with these $\mathrm{QA}$ requirements.

\subsection{LABORATORY OPERATIONS}

Laboratories performing analyses in support of this SAP shall have approved and implemented quality assurance (QA) plans. These QA plans shall meet the minimum requirements of Hanford Analytical Services Quality Assurance Requirements Document (DOE 1998) as a baseline for laboratory quality systems. 222-S Laboratory Quality Assurance Plan (Markel 1999) specifies the requirements for assuring the quality of sample analysis conducted at the 222-S Laboratory.

Analytical quality control (QC) requirements (duplicates, spikes, blanks, laboratory control samples) are identified in Tables 3-1, 3-2, and 4-1. The laboratory shall also use calibration and calibration check standards appropriate for the analytical instrumentation being used (see DOE [1998] for definitions of QC samples and standards). The criteria presented are goals for demonstrating reliable method performance. It is understood that the laboratory will follow its internal QC system for required actions whenever $\mathrm{QC}$ failures occur. If sample $\mathrm{QC}$ failures occur or if any analyses cannot be performed (e.g., insufficient sample), analysts shall consult with supervisors/customers to determine the proper action. The laboratory should provide a suggested course of action at that time. All sample QC failures and limitations on the associated data shall be discussed in the narrative of the data report. Proper notification of all data not meeting QC requirements shall be included with the data.

\subsection{SAMPLE COLLECTION}

Before sampling can be performed on a tank, available risers must be identified for use in the sampling event. The selected risers must be inspected and prepared to confirm their ability to be used in sampling. Safety hazards must be identified and special precautions must be taken if needed. If deemed necessary by the sampling cognizant engineers and tank coordinator, video surveillance should be performed to identify any potential problems that may occur during the sampling event.

Samples are to be taken from a tank and shipped to the performing laboratory by Characterization Project Operations (CPO) in accordance with the respective work package(s). The chain-of- 
custody form for this work package shall identify samples by a unique number for each sample. Pertinent sampling information (e.g., unusual waste characteristics or sampling problems) should be noted in the comments section of the chain-of-custody form.

Characterization Project Operations should transport each sample collected to the performing laboratory within 3 calendar days of removing the sample from the tank. A verbal notification by CPO is to be made to the 222-S Laboratory at 373-2435 at least 24 hours in advance of an expected shipment.

Table 4-1. QC Precision and Accuracy Requirements for the Analyses

\begin{tabular}{|c|c|c|c|c|}
\hline sing & 桨 & 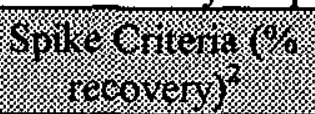 & Mation. & 19.8. \\
\hline \multicolumn{5}{|l|}{ 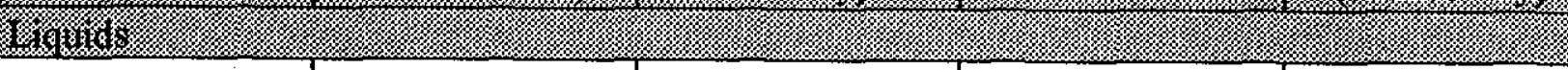 } \\
\hline DSC & $\leq 30$ & N/A & N/A & $80-120$ \\
\hline TGA & $\leq 20$ & N/A & N/A & $80-120$ \\
\hline Bulk density & N/A & N/A & N/A & N/A \\
\hline Specific gravity & $\leq 20$ & N/A & N/A & N/A \\
\hline ICP/AES & $\leq 20$ & $75-125$ & $<\mathrm{EQL}$ & $80-120$ \\
\hline ICP/MS & $\leq 20$ & $75-125$ & $<\mathrm{EQL}$ & $80-120$ \\
\hline IC & $\leq 20$ & $75-125$ & $<\mathrm{EQL}$ & $80-120$ \\
\hline TIC/TOC & $\leq 20$ & $75-125$ & $<\mathrm{EQL}$ & $80-120$ \\
\hline $\mathrm{OH}$ & $\leq 20$ & N/A & $<\mathrm{EQL}$ & $80-120$ \\
\hline $\mathrm{pH}$ & $\leq 20$ & N/A & N/A & $\pm 0.1 \mathrm{pH}$ unit \\
\hline AEA & $\leq 20$ & $75-125^{5}$ & $<\mathrm{MDA}$ & $70-130$ \\
\hline GEA & $\leq 20$ & N/A & $<\mathrm{MDA}$ & NP \\
\hline${ }^{90} \mathrm{Sr}$ & $\leq 20$ & $75-125^{5}$ & $<\mathrm{MDA}$ & $75-125$ \\
\hline Ammonia & $\leq 20$ & $75-125$ & $<\mathrm{EQL}$ & $80-120$ \\
\hline U Total & $\leq 20$ & $75-125$ & $<\mathrm{EQL}$ & $80-120$ \\
\hline${ }^{99} \mathrm{Tc}$ & $\leq 20$ & $75-125$ & $<\mathrm{MDA}$ & $80-120$ \\
\hline CVAA & $\leq 20$ & $75-125$ & $<\mathrm{EQL}$ & $80-120$ \\
\hline GFAA & $\leq 20$ & $75-125$ & $<\mathrm{EQL}$ & $80-120$ \\
\hline${ }^{3} \mathrm{H}$ & $\leq 20$ & N/A & $<\mathrm{MDA}$ & $80-120$ \\
\hline${ }^{14} \mathrm{C}$ & $\leq 20$ & $75-125$ & $<\mathrm{MDA}$ & $80-120$ \\
\hline${ }^{129} \mathrm{I}$ & $\leq 20$ & $\mathrm{~N} / \mathrm{A}^{5}$ & $<\mathrm{MDA}$ & $\mathrm{NP}$ \\
\hline Caustic demand & N/A & N/A & N/A & N/A \\
\hline \multicolumn{5}{|l|}{ 6rings: } \\
\hline DSC & $\leq 30$ & N/A & N/A & $80-120$ \\
\hline TGA & $\leq 30$ & N/A & N/A & $80-120$ \\
\hline Bulk density & N/A & N/A & N/A & N/A \\
\hline ICP/AES & $\leq 20$ & $75-125$ & $<\mathrm{EQL}$ & $80-120$ \\
\hline ICP/MS & $\leq 20$ & $75-125$ & $<\mathrm{EQL}$ & $80-120$ \\
\hline IC & $\leq 20$ & $75-125$ & $<\mathrm{EQL}$ & $80-120$ \\
\hline
\end{tabular}


Table 4-1. QC Precision and Accuracy Requirements for the Analyses

\begin{tabular}{|c|c|c|c|c|}
\hline 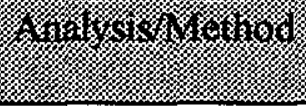 & r. & 4. & 19.9. & 1. \\
\hline TIC/TOC & $\leq 20$ & $75-125$ & $<\mathrm{EQL}$ & $80-120$ \\
\hline $\mathrm{OH}$ & $\leq 20$ & $75-125$ & $<\mathrm{EQL}$ & $80-120$ \\
\hline $\mathrm{pH}$ & $\leq 20$ & N/A & N/A & $\pm 0.1 \mathrm{pH}$ unit \\
\hline AEA & $\leq 20$ & $75-125^{5}$ & $<\mathrm{MDA}$ & $70-130$ \\
\hline GEA & $\leq 20$ & N/A & $<\mathrm{MDA}$ & NP \\
\hline${ }^{90} \mathrm{Sr}$ & $\leq 20$ & $75-125^{5}$ & $<$ MDA & $75-125$ \\
\hline Ammonia & $\leq 20$ & $75-125$ & $<\mathrm{EQL}$ & $80-120$ \\
\hline U Total & $\leq 20$ & $75-125$ & $<\mathrm{EQL}$ & $80-120$ \\
\hline${ }^{99} \mathrm{Tc}$ & $\leq 20$ & $75-125$ & $<\mathrm{MDA}$ & $80-120$ \\
\hline CVAA & $\leq 20$ & $75-125$ & $<\mathrm{EQL}$ & $80-120$ \\
\hline GFAA & $\leq 20$ & $75-125$ & $<\mathrm{EQL}$ & $80-120$ \\
\hline${ }^{3} \mathrm{H}$ & $\leq 20$ & N/A & $<\mathrm{MDA}$ & $80-120$ \\
\hline${ }^{14} \mathrm{C}$ & $\leq 20$ & $75-125$ & $<\mathrm{MDA}$ & $80-120$ \\
\hline${ }^{129} \mathrm{I}$ & $\leq 20$ & $\mathrm{~N} / \mathrm{A}^{5}$ & $<\mathrm{MDA}$ & $\mathrm{NP}$ \\
\hline Wt $\%$ oxides & N/A & N/A & N/A & TBD \\
\hline Caustic demand & N/A & N/A & N/A & N/A \\
\hline
\end{tabular}

Notes:

$\mathrm{N} / \mathrm{A}=$ not applicable

$\mathrm{NP}=$ not performed

$\mathrm{MDA}=$ minimum detectable activity

$E Q L=$ estimated quantitation limit

$\mathrm{LCS}=$ laboratory control standard

${ }^{1}$ For the calculation of the relative percent difference (RPD), both the sample and duplicate results must exceed the EQL or MDA. Failures are permissible if the requirements in the $\mathrm{QA}$ section are followed.

${ }^{2}$ The criteria are recommended. Failures are permissible if the requirements in the QA section are followed.

${ }^{3}$ When a blank exceeds the EQL or MDA, sample results that exceed the contribution from the blank twenty-fold or more are reportable. See also the QA section of this SAP.

${ }^{4}$ For some analyses, this could be a method spike or a blank spike. Ranges are percent recovery of theoretical.

${ }^{5} \mathrm{~A}$ tracer or carrier may be substituted for the spike.

\subsection{SAMPLE CUSTODY}

The chain-of custody form is initiated by the sampling team as described in the work package. Samples are shipped in a sample pig and sealed with a Waste Tank Sample Seal (see below).

\begin{tabular}{|l|l|}
\hline & Y \\
\hline Supervisor: & Sample No.: \\
\hline Date of Sampling: & Time of Sampling: \\
\hline Shipment No.: & Serial No.: \\
\hline
\end{tabular}




\section{RPP-5570, Rev. 0}

The sealed and labeled samples are shipped to the laboratory along with the chain-of-custody form. The receipt and control of samples in the 222-S Laboratory are described in laboratory procedure LO-090-101. 
RPP-5570, Rev. 0

\subsection{EXCEPTIONS, CLARIFICATIONS, AND ASSUMPTIONS}

\subsection{EXCEPTIONS TO DQO REQUIREMENTS}

Baldwin (1999) requests that any samples obtained for Compatibility also be analyzed to confirm or determine the low-activity waste and/or high-level waste envelopes (as defined by Tables 4.1 through 4.4 of Nguyen 1999b and Tables 4.1 and 4.2 of Nguyen 1999a, respectively). In general, liquid grab samples obtained for Compatibility will also be analyzed for the low-activity waste envelope analytes. Analysis for high-level waste envelope analytes and/or the analysis of solids will depend on the waste type that is sampled and will be addressed on a tank-by-tank basis.

Directions for the analysis of specific tank samples for envelope analytes and other special instructions are provided in Table 5-1.

\subsection{CLARIFICATIONS AND ASSUMPTIONS}

Any exothermic reaction determined by differential scanning calorimetry (DSC) must be reported on a dry weight basis as shown in equation 1 using the weight percent water determined from thermogravimetric analysis (TGA).

$$
\text { Exotherm }(\text { dry weight })=\frac{[\text { exotherm }(\text { wet weight }) \times 100]}{(100-\% \text { water })}
$$

Note: A large error in the DSC value may result when converting samples containing greater than 90 percent water to a dry weight basis. However, this conversion is still required.

The laboratory is requested to report all analytical results recovered from the inductively coupled plasma - atomic emission spectroscopy (ICP/AES) and ion chromatography (IC) analyses, even though only specific analytes are requested. These opportunistic analyses (Kristofzski 1996) are to be reported only if no additional preparatory work is required (e.g., running additional standards) and if the error associated with the results are documented. No reruns nor additional analyses should be performed to improve recovery for analytes not specifically requested in Tables 3-1 or 3-2.

\subsection{PRIORITIES FOR COMPATIBILITY GRAB SAMPLES}

In the event that the sample material recovered is insufficient to perform all the analyses prescribed by this SAP, the analyses have been prioritized (from highest to lowest priority) as follows: 
RPP-5570, Rev. 0

1. Ammonia (for single-shell tank and double-contained receiver tank samples), hydroxide, ion chromatography, and $\mathrm{pH}$.

2. Separable organics, DSC, and TGA

3. Specific gravity/bulk density

4. Volume percent solids, ${ }^{235 / 238} \mathrm{U},{ }^{239 / 240} \mathrm{Pu},{ }^{241} \mathrm{Am}, \mathrm{ICP} / \mathrm{AES}$ ( $\mathrm{Al}, \mathrm{Fe}, \mathrm{Cr}, \mathrm{Mn}, \mathrm{Ni}, \mathrm{Zr}$ )

5. TOC, ICP/AES (Na)

6. ${ }^{90} \mathrm{Sr},{ }^{137} \mathrm{Cs}$

7. Other analytes listed in Tables 3-1 and 3-2.

Table 5-1. Tank-Specific Analytical Exceptions

\begin{tabular}{|l|l|}
\hline $241-S Y-102$ & $\begin{array}{l}\text { Samples 2SY-99-5 through 2SY-99-9 do not require analysis for Waste } \\
\text { Feed Delivery low-activity waste or high-level waste envelope analytes. }\end{array}$ \\
\hline
\end{tabular}


RPP-5570, Rev. 0

\subsection{ORGANIZATION}

The organization and responsibility of key personnel involved with these tank characterization projects are listed in Table 6-1.

Table 6-1. Tank Project Key Personnel

\begin{tabular}{|c|c|c|}
\hline 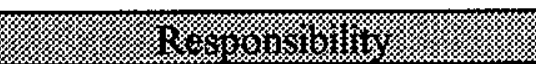 & 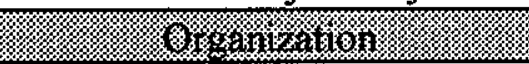 & 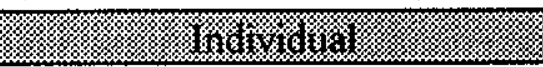 \\
\hline $\begin{array}{l}\text { Manager, Data Development } \\
\text { and Interpretation }\end{array}$ & $\begin{array}{l}\text { RPP Process Engineering } \\
\text { (CHG) }\end{array}$ & J. G. Field, 376-3753 \\
\hline $\begin{array}{l}\text { Process Engineering point of } \\
\text { contact for Compatibility } \\
\text { Samples }\end{array}$ & $\begin{array}{l}\text { RPP Process Engineering } \\
\text { (CHG) }\end{array}$ & L. M. Sasaki, 373-1027 \\
\hline $\begin{array}{l}\text { Process Engineering point of } \\
\text { contact for Stabilization }\end{array}$ & $\begin{array}{l}\text { RPP Process Engineering } \\
\text { (CHG) }\end{array}$ & J. G. Field, 376-3753 \\
\hline $\begin{array}{l}\text { Double-Shell Tank Farm } \\
\text { Compatibility Program point } \\
\text { of contact }\end{array}$ & $\begin{array}{l}\text { Double-Shell Tank Farms: } \\
\text { Engineering (CHG) }\end{array}$ & T. M. Blaak, 373-3880 \\
\hline $\begin{array}{l}\text { Single-Shell Tank Farm } \\
\text { Compatibility Program point } \\
\text { of contact }\end{array}$ & SST Engineering (CHG) & R. E. Larson, 373-9100 \\
\hline Manager, Field Sampling & $\begin{array}{l}\text { Characterization Project } \\
\text { Operations (CHG) }\end{array}$ & J. F. Sickels, 373-0259 \\
\hline $\begin{array}{l}\text { 222-S Laboratory point of } \\
\text { contact (day shift) }\end{array}$ & $\begin{array}{l}\text { Hanford Analytical Laboratory } \\
\text { Operations (FDH) }\end{array}$ & $\begin{array}{l}\text { W. I. Winters (NHC), 373- } \\
1951\end{array}$ \\
\hline $\begin{array}{l}\text { 222-S Laboratory point of } \\
\text { contact (off hours) }\end{array}$ & Analytical Services (FDH) & $\begin{array}{l}\text { 222-S Laboratory shift } \\
\text { manager, 373-2435 } \\
\end{array}$ \\
\hline $\begin{array}{l}\text { Process Engineering point of } \\
\text { contact for immediate } \\
\text { notifications }\end{array}$ & $\begin{array}{l}\text { RPP Process Engineering } \\
\text { (CHG) }\end{array}$ & $\begin{array}{l}\text { On-Čall Process Engineer, } \\
539-2074 \text { or } 85-9654 \text { (pager) }\end{array}$ \\
\hline $\begin{array}{l}\text { Double-Shell Tank Farm point } \\
\text { of contact }\end{array}$ & Tank Farm Operations & $\begin{array}{l}\text { Double-Shell Tank Farm } \\
\text { Operations shift manager, 373- } \\
2689\end{array}$ \\
\hline $\begin{array}{l}\text { Single-Shell Tank Farm point } \\
\text { of contact }\end{array}$ & Tank Farm Operations & $\begin{array}{l}\text { Single-Shell Tank Farm } \\
\text { Operations shift manager, 373- } \\
3475\end{array}$ \\
\hline
\end{tabular}


RPP-5570, Rev. 0

\subsection{DELIVERABLES}

All analyses will be reported as Format I, II, or IV as indicated in Tables 3-1 and 3-2. Additional information regarding reporting formats is given in Schreiber (1998).

\subsection{FORMAT I REPORTING}

Tables 3-1 and 3-2 contain the notification limits for selected analytes. Any results exceeding their notification limits shall be reported via telephone to the Process Engineering On-Call Process Engineer and/or the appropriate Tank Farm Operations shift manager as soon as the data are obtained and reviewed by the responsible scientist. This verbal notification must be followed within one hour by electronic notification to Process Engineering On-Call Process Engineer (and the Tank Farm Operations shift manager, if required), the RPP Process Engineering Data Development and Interpretation manager, and the Process Engineering point of contact for Compatibility Samples. Additional analyses for verification purposes may be contracted between the performing laboratory and Process Engineering by either a revision to this SAP or by a letter.

\subsection{FORMAT II REPORTING}

A letter report documenting the results of the analyses shall be issued to the RPP Process Engineering Data Development and Interpretation manager, the tank coordinator responsible for the tank, the Process Engineering point of contact for Stabilization, and the point of contact for Tank Farm Compatibility Samples within 90 days of the receipt of the sample at the laboratory loading dock. If a turnaround time of less than 90 days is required for specific samples to meet tank farm needs, the turnaround time will be negotiated with Analytical Services and included in Section 5.0. The format II report is not required to contain supporting raw data, QC results, or associated analytical procedure numbers. However, the results require review and approval by the cognizant scientist or manager of the laboratory operation.

\subsection{FORMAT IV REPORTING}

The format IV report shall be a data package reporting the results of analyses performed and will resemble a regulatory data package without third party validation. The data package should be prepared by tank and include the data for all sample, including (as applicable) composites, solids, liquids, and associated blanks taken and analyzed for the sampling event. The recommended reporting format and the raw data that shall be included are given in detail in Section A5.0 of Schreiber (1998). This data package shall be issued as a document approved for public release through the document control system within 120 calendar days of the receipt of the last sample at the laboratory sample receiving/loading dock. The raw data shall be accessible to the program in accordance with the laboratory's Records Inventory and Disposition Schedule and until the respective waste tank is closed or the waste is treated. 


\section{RPP-5570, Rev. 0}

In addition to this data package, an electronic version of the analytical results shall be provided to the Tank Characterization Database representative on the same day that the final data package is issued. The data must be available to the Washington State Department of Ecology within 7 days of the release of the data package. The electronic version shall be in the standard electronic format (Lang et al.1999). 
RPP-5570, Rev. 0

\subsection{CHANGE CONTROL}

Under certain circumstances, it may become necessary for the performing laboratory to make decisions concerning a sample without review of the data by the customer of the Characterization Project. All significant changes (such as analysis of new samples) shall be documented by RPP Process Engineering via an engineering change notice to this SAP or by a letter. All changes shall also be clearly documented in the final data report. Insignificant changes may be made by the tank coordinator by placing a notation in the permanent record (i.e., note change in laboratory notebook or memo to file). Significance is determined by the tank coordinator.

At the request of the Characterization Project, additional analysis of sample material from this characterization project shall be performed following a revision of this SAP or issuance of a letter. 
RPP-5570, Rev. 0

\subsection{REFERENCES}

Baldwin, J.H., 1999, Letter of Instruction for Laboratory Work to Determine LAW and HLW Waste Feed Envelopes When Compatibility Tests are Conducted, (letter 82400-99-073 to J. G. Field, November 18), Lockheed Martin Hanford Corporation, Richland, Washington.

Board, D. C., 1998, Tank Waste Remediation System, Characterization Project, Quality Policies, HNF-SD-WM-QAPP-025, Rev. 4, Lockheed Martin Hanford Corp. for Fluor Daniel Hanford, Inc., Richland, Washington.

DOE, 1998, Hanford Analytical Services Quality Assurance Requirements Document, DOE/RL96-68, Rev. 2, U.S. Department of Energy, Richland Field Office, Richland, Washington.

Fowler, K. D., 1999, Tank Farm Waste Transfer Compatibility Program, HNF-SD-WM-OCD015, Rev. 2, Lockheed Martin Hanford Corp. for Fluor Daniel Hanford, Inc., Richland, Washington.

Kristofzski, J. G., 1996, Directions for "Opportunistic Analyses, "(memorandum 75310-96-168 to J. H. Baldwin, et al., September 11), Westinghouse Hanford Company, Richland, Washington.

Lang, L. L., Bobrowski, S. F., and S. J. Harris, 1999, Standard Electronic Format Specification for Tank Characterization Data Loader: Version 3:0, HNF-3638, Rev. 1, prepared by Pacific Northwest National Laboratory for Lockheed Martin Hanford Corp., Richland, Washington.

LMHC, 1999, Nonconforming Item Reporting and Control, LMH-PRO-298, Rev. 0, Lockheed Martin Hanford Corporation, Richland, Washington.

Markel, L. P., 1999, 222-S Laboratory Quality Assurance Plan, HNF-SD-CP-QAPP-016, Rev. 3C, Waste Management Hanford, Inc., for Fluor Daniel Hanford, Inc., Richland, Washington.

Mulkey, C. H., M. Miller, and L. Jackson, 1999, Data Quality Objectives for Tank Farms Waste Compatibility Program, HNF-SD-WM-DQO-001, Rev. 3, Lockheed Martin Hanford Corp. for Fluor Daniel Hanford, Inc., Richland, Washington.

Nguyen, D. M., 1999a, Data Quality Objectives for TWRS Privatization Phase I: Confirm Tank $T$ is an Appropriate Feed Source for Low-Activity Waste Feed Batch X, HNF-1796, Rev. 2, Lockheed Martin Hanford Corp. for Fluor Daniel Hanford, Inc., Richland, Washington.

Nguyen, D. M., 1999b, Data Quality Objectives for RPP Privatization Phase I: Confirm Tank T is an Appropriate Feed Source for High-Level Waste Feed Batch $X, \mathrm{RPP}-1558$, Rev. 2, Lockheed Martin Hanford Corp. for Fluor Daniel Hanford, Inc., Richland, Washington. 


\section{RPP-5570, Rev. 0}

Schreiber, R. D., 1998, Fiscal Year 1999 Memorandum of Understanding for the TWRS

Characterization Project, HNF-3578, Rev. 0A, Lockheed Martin Hanford Corp. for Fluor Daniel Hanford, Inc., Richland, Washington. 